\title{
IMPLEMENTASI JUAL BELI DALAM PERIKATAN SYARI'AH DAN KONVENSIONAL
}

\author{
Evy Septiana \\ Institut Agama Islam Negeri Metro \\ Email:evyzaen2008@gmail.com \\ Nurul Mahmudah \\ Institut Agama Islam Negeri Metro \\ Email:mafazasyafira@gmail.com

Tapis : Jurnal Penelitian Ilmiah
Website: $\frac{\text { http://e-journal.metrouniv.ac.id/index.php/tapis/index }}{\text { DOI: http://dx.doi.org/10.32332/tapis.v2i2.1326 }}$
the Creative Commons Attribution-NonCommercial 4.0 International License
This article is distributed under the terms of

\begin{abstract}
Along with the development of technology, people work together to create convenience in conducting transactions or muamalah, one of them is in term of buying and selling. Today, people can buy goods without coming directly to the seller. This certainly facilitates people for tricking. For these reasons, this research was conducted to understand the difference between Islamic and conventional practice on buying and selling engagements.

This descriptive qualitative study employed literature study which obtained the result that even though the rules of all goods may be sold, but in Islam, it must not be contradicted with the quran, hadith, and benefit principle. Whereas, in conventional engagement, all goods can be absolutely sold, as long as there is willingness from both parties.
\end{abstract}

Keywords: Impelmentation of Buying and Selling, Islamic Economic, Convensional Economic

\begin{abstract}
Abstrak
Seiring dengan berkembangnya teknologi, manusia saling bersinergi dalam menciptakan kemudahan melakukan transaksi atau muamalah, salah satunya dalam praktik jual beli. Sebagaimana kita ketahui bahwa seseorang dapat membeli barang tanpa harus datang langsung menemui penjualnya. Hal ini tentu membuka pintu kecurangan dalam bertaransaksi. Oleh karena itu penelitian ini hadir untuk mengkaji praktik jual beli syari'ah dan perbedaanya dengan jual beli dalam perikatan konvensional.

Pendekatan dalam penelitian ini adalah kualitatif deskriptif dengan jenis penelitian studi pustaka. Berdasarkan hasil penelitian, secara syari'at, walaupun pada kaidahnya semua barang boleh dijual, namun tidak boleh
\end{abstract}


bertentang dengan al- qur'an, hadits, dan asas kemaslahatan. Sedangkan dalam perikatan konvensional, semua barang dapat secara mutlak untuk dijual, selama ada kerelaan dari kedua belah pihak.

Kata Kunci: Jual Beli, Ekonomi Syariah, Ekonomi Konvensional

\section{A. PENDAHULUAN}

Agama Islam mengatur setiap segi kehidupan umatnya. Mengatur hubungan seorang hamba dengan Tuhannya yang biasa disebut dengan muamalah ma'allah dan mengatur pula hubungan dengan sesamanya yang biasa disebut dengan muamalah ma'annas. Hubungan dengan sesama inilah yang melahirkan suatu cabang ilmu dalam Islam yang dikenal dengan Fiqih Muamalah. Aspek kajian Fikih Muamalah adalah sesuatu yang berhubungan dengan hubungan antar umat manusia, mulai dari jual beli, sewa menyewa, hutang piutang dan lain-lain.

Salah satu cara dalam memenuhi kebutuhan hidup setiap hari, manusia biasanya melakukan transaksi jual beli. Penjual dan pembeli saling menukar barang dengan dengan kesepakatan dari kedua belah pihak. Pada jaman dahulu transaksi jual beli biasanya dilakukan secara langsung, dimana kedua belah pihak saling bertemu. Namun pada jaman sekarang, seiring dengan kemajuan teknologi, transaksi jual beli biasa dilakukan tanpa batasan ruang. Maraknya penggunaan internet membuat pelaku jual beli dapat bertransaksi dengan lancar tanpa harus saling bertemu dan melihat barang yang dijualbelikan secara langsung. Sedangkan di dalam Islam, transaksi jual beli harus dilakukan dengan cara jujur tanpa mengandung unsur penipuan ataupun keraguraguan. Hal ini yang kemudian menibulkan berbagai pertanyaan tentang bagaimana jual beli dalam perikatan syari'ah (hukum Islam), dan perbedaannya dengan jual beli dalam perikatan konvensional.

\section{B. KAJIAN TEORI}

\section{Jual Beli Dalam Perikatan Syari'ah}

Dalam perikatan syari'ah, secara bahasa jual beli terdiri dari dua kata, yaitu "jual" dan "beli". Kedua kata ini dalam bahasa Arab sama dengan al-bai' dan al-syira'. Keduanya merupakan rangkaian makna timbal balik. Di dalam al-Qur'an kedua kata itu disebutkan secara terpisah tetapi mempunyai makna bersamaan. Kadang-kadang al- 
Qur'an menyebut al-bai' dan di tempat lain menyebut al-syira' saja. Namun keduanya mempunyai makna yang berbeda karena adanya penjualan pasti ada pembelian, demikian sebaliknya. ${ }^{1}$

Secara terminology, jual beli memiliki makna yang luas. Segala bentuk yang berkaitan dengan proses pemindahan hak milik barang atau asset kepada orag lain termasuk dalam lingkup pengertian jual beli. Jual beli bisa berupa pertukaran barang dengan barang atau barter (muqayyad), uang dengan uang (sharf), atau barang dengan uang (mutlaq). ${ }^{2}$

Jual beli di dalam Islam harus dilakukan secara jujur dan dan terus terang. Sebagaimana yang telah diajarkan oleh Nabi SAW pada saat beliau membangun pasar pada tahun pertama Hijriyah sebagai tempat interaksi jual beli. Sebagaimana dalam sabdanya:

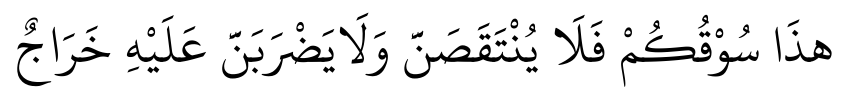

"nilah pasar kalian, jangan sampai dikurangi dan jangan juga menetapkan pajak atasnya" (HR. Ibnu Majah). ${ }^{3}$

Ada beberapa pesan beliau untuk menjadi seorang pedagang yang sukses dan diridhoi Allah SWT, Rasulullah SAW telah menentukan indikator jual beli yang mabrur dalam sebuah haditst:

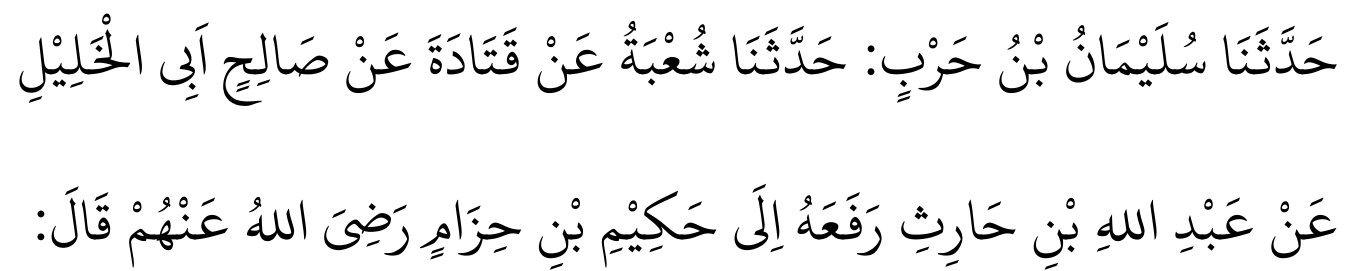

${ }^{1}$ Dede Nurohman, Memahami Dasar-Dasar Ekonomi Islam (Yogyakarta: Teras, 2011), P. 62.

2 Dede Nurohman, P. 63.

3 SKJ: Islam Untuk Kesejahteraan Masyarakat, P. 32, accessed December 31, 2018, https://books.google.com/books/about/SKJ_Islam_Untuk_Kesejahteraan_Masyarakat.html?i d=7JBBDwAAQBAJ. 


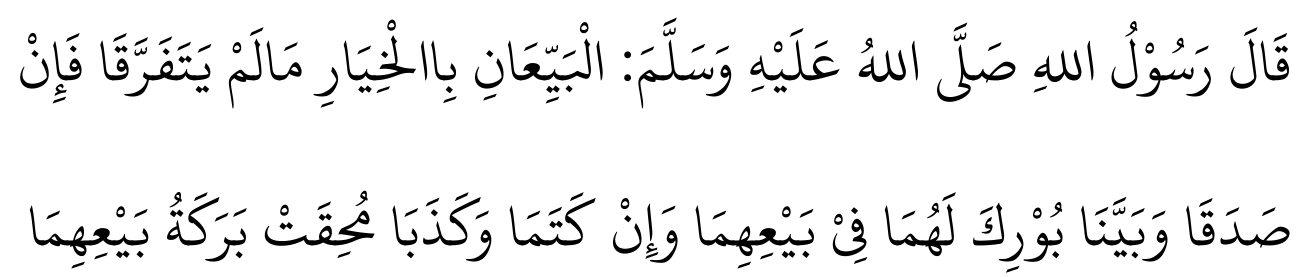

"Sulaiman bin Harb menyampaikan kepada kami dari Syu'bah, dari Qatadah, dari Shalih Abu al-Khalil, dari Abdullah bin al-Harits, dari Hakim bin Hizam bahwa Rasulullah SAW bersabda, "penjual dan pembeli memiliki hak khiyar (memilih) selama mereka belum berpisah atau sampai mereka berpisah. Jika mereka berdua jujur dan berterus terang, jual beli mereka akan diberkahi, dan jika mereka menyembunyikan aib dan berdusta, keberkahan dalam jual beli mereka akan hilang"

Al-Qur'an adalah sumber pertama dan utama dalam ekonomi Islam. Di dalamnya dapat ditemui hal ihwal yang berkaitan dengan ekonomi dan juga terdapat hukum-hukum dan undang-undang diharamkannya riba, dan diperbolehkannya jual beli. ${ }^{4}$ Allah SWT berfirman:

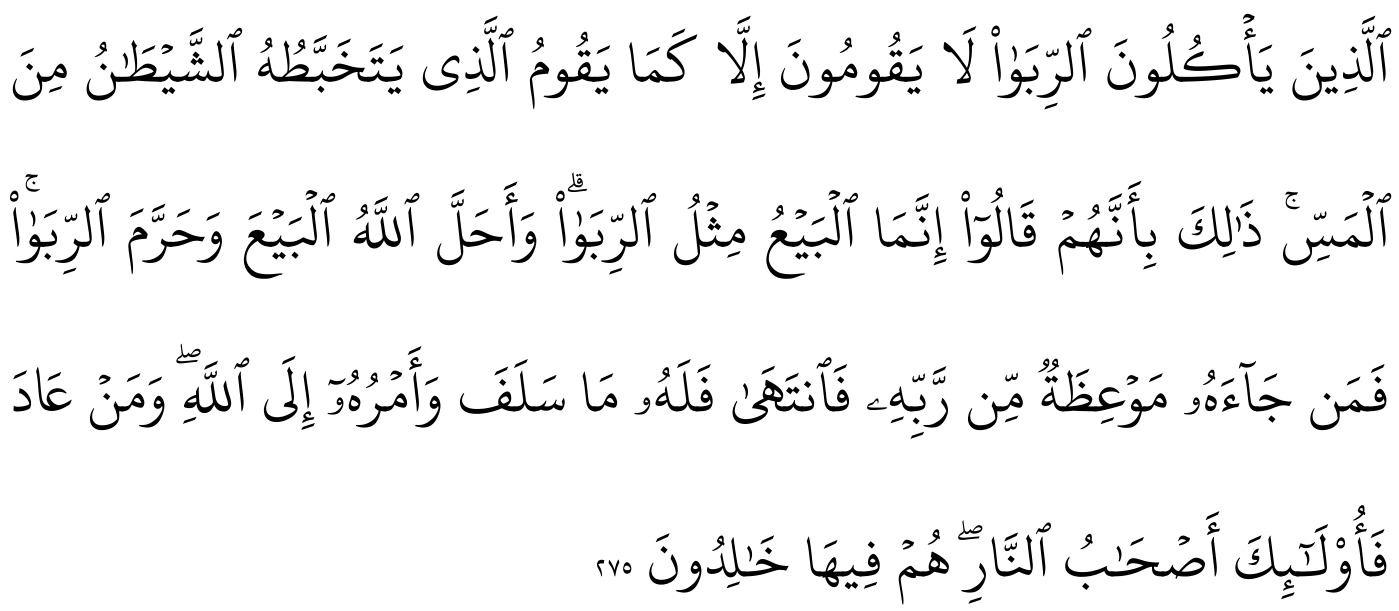

"Orang-orang yang makan (mengambil) riba tidak dapat berdiri melainkan seperti berdirinya orang yang kemasukan syaitan lantaran (tekanan) penyakit gila. Keadaan mereka yang demikian itu, adalah disebabkan mereka berkata (berpendapat), sesungguhnya jual beli itu sama dengan riba, padahal Allah telah menghalalkan jual beli dan mengharamkan riba. Orang-orang yang telah sampai kepadanya larangan dari Tuhannya, lalu terus berhenti (dari mengambil riba), maka baginya apa yang telah diambilnya dahulu (sebelum datang larangan); dan urusannya (terserah) kepada Allah. Orang yang kembali (mengambil riba), maka orang itu adalah penghuni-penghuni neraka; mereka kekal di dalamnya." 5

\footnotetext{
${ }^{4}$ Ahmad Izzan and Syahri Tanjung, Referensi Ekonomi Syari'ah (Bandung: Remaja Rosdakarya, 2006), P. 32.

${ }^{5}$ Departemen Agama RI, Al-Qur'an Dan Terjemahannya (Bandung: Diponegoro, 2008).
} 
Riba adalah haram dan jual beli adalah halal. Jadi tidak semua akad jual beli adalah haram sebagaimana yang disangka oleh sebagian orang berdasarkan ayat ini. Hal ini dikarenakan huruf alif dan lam dalam ayat tersebut untuk menerangkan jenis, dan bukan untuk yang sudah dikenal karena sebelumnya tidak disebutkan dalam kalimat al-bai' yang dapat dijadikan referensi, dan jika ditetapkan bahwa jual-beli adalah umum, maka ia dapat dikhususkan dengan apa yang telah disebutkan berupa riba dan yang lainnya dari benda yang dilarang untuk diakadkan seperti minuman keras, bangkai dan yang lainnya dari apa yang disebutkan dalam sunnah dan ijma' para ulama' akan larangan tersebut. 6

Adapun dalil sunnah di antaranya adalah hadist yang diriwayatkan dari Rasulullah SAW. Beliau bersabda: “sesungguhnnya jual beli itu atas dasar saling ridha." Ketika ditanya usaha apa yang paling utama, Nabi SAW menjawab: “Usaha seseorang yang dengan tangannya sendiri, dan setiap jual beli yang mabrur." Jual beli yang mabrur adalah setiap jual beli yang tidak ada dusta dan khianat, sedangkan dusta itu adalah diantaranya penyamaran barang yang dijual, dan penyamaran itu adalah menyembunyikan aib barang dari penglihatan pembeli. Adapun makna khianat ia lebih umum dari itu, sebab selain menyamarkan dari bentuk barang yang dijual, sifat, atau hal-hal luar seperti dia menyifatkan dengan sifat yang tidak benar atau memberi tahu harga yang dusta. ${ }^{7}$

Dalil lainnya adalah: Dari Suaib ar-Rumi ra bahwa Rasulullah SAW bersabda, “Tiga hal yang di dalamnya terdapat keberkahan: jual beli secara tangguh, mudharabah dan mencampur gandum dengan tepung untuk keperluan rumah, bukan untuk dijual." (HR. Ibnu Majah) ${ }^{8}$.

\section{Rukun Jual Beli}

Rukun jual beli ada tiga: yaiu sighat adalah ijab dan qabul. Ijab seperti yang diketahui sebelumnya diambil dari kata aujaba yang artinya meletakkan dari pihak penjual yaitu pemberian hak milik, dan qabul yaitu orang yang menerima hak milik. Jadi

${ }^{6}$ Abdul Aziz Muhammad Azzam, Fiqh Muamalat (Jakarta: Amza, 2010), P. 26.

${ }^{7}$ Abdul Aziz Muhammad Azzam, P. 27.

${ }^{8}$ Heri Sudarsono, Bank Dan Lembaga Keuangan Syari'ah (Yogyakarta: Ekonisa, 2013), P. 62. 
dalam akad jual beli, penjual selalu menjadi yang berijab dan pembeli menjadi penerima baik diawal atau diakhir lafalnya. ${ }^{9}$ Kemudian 'Aqidan (kedua belah pihak yan berakad). Jika dikatakan kata 'aqidan, maka perhatian langsung tertuju kepada penjual dan pembeli karena keduanya mempunyai andil dalam terjadinya pemilikan dengan harga.. Selanjutnya Ma'qud 'Alaih (Barang yang diakadkan). Mauqud 'alaih yaitu harga yang akan dipindahkan dari tangan salah seorang yang berakad kepada pihak lain, baik harga atau barang berharga. ${ }^{10}$

Transaksi jual-beli baru dinyatakan terjadi apabila terpenuhi tiga syarat jual-beli, yaitu: Adanya dua pihak yang melakukan transaksi jual-beli, Adanya sesuatu atau barang yang dipindahtangankan dari penjual kepada pembeli, Adanya kalimat yang menyatakan terjadinya transaksi jual-beli (sighat ijab qabul) ${ }^{11}$.

\section{Syarat Jual Beli}

Adapun Syarat yang harus dipenuhi oleh penjual dan pembeli adalah Agar tidak terjadi penipuan, maka keduanya harus berakal sehat dan dapat membedakan (memilih). Dengan kehendaknya sendiri, keduanya saling merelakan, bukan karena terpaksa. Dewasa atau baligh. Syarat benda dan uang yang diperjual belikan sebagai berikut:

1. Bersih atau suci barangnya: tidak sah menjual barang yang najis seperti anjing, babi, khomar dan lain-lain yang najis.

2. Ada manfaatnya: jual beli yang ada manfaatnya sah, sedangkan yang tidak ada manfaatnya tidak sah, seperti jual beli lalat, nyamuk, dan sebagainya.

3. Dapat dikuasai: tidak sah menjual barang yang sedang lari, misalnya jual beli kuda yang sedang lari yang belum diketahui kapan dapat ditangkap lagi, atau barang yang sudah hilang atau barang yang sulit mendapatkannya.

4. Milik sendiri: tidak sah menjual barang orang lain dengan tidak seizinnya, atau barang yang hanya baru akan dimilikinya atau baru akan menjadi miliknya.

\footnotetext{
${ }^{9}$ Abdul Aziz Muhammad Azzam, Fiqh Muamalat, P. 29.

10 Abdul Aziz Muhammad Azzam, P. 47.

${ }^{11}$ Mahmud Yunus and Nadlrah Naimi, Fiqih Muamalah (Medan: Ratu Jaya, 2011), P.
} 104-105. 
5. Mestilah diketahui kadar barang atau benda dan harga itu, begitu juga jenis dan sifatnya. Jual beli benda yang disebutkan sifatnya saja dalam janji (tanggungan), maka hukumnya boleh.

Jual beli dapat ditinjau dari berbagai segi, yaitu:

1. Ditinjau dari segi bendanya dapat dibedakan menjadi:

a) Jual beli benda yang kelihatan, yaitu jual beli yang pada waktu akad, barangnya ada di hadapan penjual dan pembeli.

b) Jual beli salam, atau bisa juga disebut dengan pesanan. Dalam jual beli ini harus disebutkan sifat-sifat barang dan harga harus dipegang ditempat akad berlangsung.

c) Jual beli benda yang tidak ada, Jual beli seperti ini tidak diperbolehkan dalam agama Islam.

2. Ditinjau dari segi pelaku atau subjek jual beli:

a) Dengan lisan, akad yang dilakukan dengan lisan atau perkataan. Bagi orang bisu dapat diganti dengan isyarat.

b) Dengan perantara, misalnya dengan tulisan atau surat menyurat. Jual beli ini dilakukan oleh penjual dan pembeli, tidak dalam satu majlis akad, dan ini dibolehkan menurut syara'.

c) Jual beli dengan perbuatan, yaitu mengambil dan memberikan barang tanpa ijab kabul. Misalnya seseorang mengambil mie instan yang sudah bertuliskan label harganya. Menurut sebagian ulama syafiiyah hal ini dilarang karena ijab kabul adalah rukun dan syarat jual beli, namun sebagian syafiiyah lainnya seperti Imam Nawawi membolehkannya.

3. Dinjau dari segi hukumnya

Jual beli dinyatakan sah atau tidak sah bergantung pada pemenuhan syarat dan rukun jual beli yang telah dijelaskan di atas. Dari sudut pandang ini, jumhur ulama membaginya menjadi dua, yaitu: ${ }^{12}$

a) Shahih, yaitu jual beli yang memenuhi syarat dan rukunnya

\footnotetext{
12 "Kumpulan Makalah Mahasiswa," accessed April 28, 2016, http:/ / evendimuhtar.blogspot.com/2015/07/jual-beli-dalamislam.html,\%20Diakses:\%2028\%20April\%202016.
} 
b) Ghairu Shahih, yaitu jual beli yang tidak memenuhi salah satu syarat dan rukunnya.

Dalam Al-Quran atau hadits, terdapat beberapa prinsip dasar yang harus diperhatikan dalam bermuamalah. Prinsip-prinsip dasar yang di maksudkan, yaitu; pertama, asas suka sama suka, atau kerelaan yang sebenarnya, bukan kerelaan yang bersifat semu dan seketika. Oleh karena itu, Rasulullah SAW mengharamkan bai al garar (jual beli yang mengandung unsur spekulasi dan penipuan). Kedua, Asas keadilan, yaitu adanya keseimbangan, baik produksi, cara memperolehnya, maupun distribusinya. Ketiga, Asas saling menguntungkan, yaitu tidak ada satu pihak pun yang dirugikan. Terakhir, asas saling menolong dan saling membantu.

\section{PEMBAHASAN}

\section{Relefansi Jual Beli pada Perikatan Syariah}

Praktek jual beli syari'ah di Indonesia belum begitu relefan, karena masih adanya beberapa pelaku jual beli yang tidak memenuhi syarat. Contohnya adalah jual beli benda najis dan benda yang diharamkan. Yaitu jual beli babi, khomr, narkoba, dan lain sebagainya.

Di beberapa tempat masih marak sekali terjadi jual beli ijon. Yaitu jual beli tanaman yang belum kelihatan buahnya. Hal ini termasuk jual beli benda yang tidak ada dan itu dilarang dalam Islam. Karena jika buahnya ternyata tidak sesuai dengan yang diperkirakan, maka itu akan merugikan salah satu pihak. Ini melanggar asas keadilan dan asas saling menguntungkan.

\section{Jual Beli Dalam Perikatan Konvensional}

Secara etimologis, jual beli berarti menukar harta dengan harta. Sedangkan, secara terminologi, jual beli memiliki arti penukaran selain dengan fasilitas dan kenikmatan.

Menjual adalah memindahkan hak milik kepada orang lain dengan harga, sedangkan membeli yaitu menerimanya. Allah telah menjelaskan dalam kitab-Nya yang mulia demikian pula Nabi SAW dalam sunnahnya yang suci mengenai beberapa hukum muamalah, karena butuhnya manusia akan hal itu, dan karena butuhnya manusia kepada makanan yang dengannya akan menguatkan tubuh, 
demikian pula butuhnya kepada pakaian, tempat tinggal, kendaraan dan sebagainya dari berbagai kepentingan hidup serta kesempurnaanya.

Umumnya arti jual beli adalah suatu perjanjian dengan mana pihak yang satu mengikatkan dirinya untuk menyerahkan suatu kebendaan, dan pihak lain untuk membayar harga yang telah dijanjikan. Sedangkan arti dari jual beli internasional yaitu jual Beli yang bersifat lintas batas Negara. ${ }^{13}$

Menurut Pasal 1313, Buku III KUH Pdt tentang Perikatan, menyatakan bahwa "Suatu perjanjian adalah suatu perbuatan yang dilakukan oleh satu orang atau lebih yang mengikatkan dirinya terhadap satu orang lain atau lebih." Unsur-unsur yang terdapat dalam Pasal 1313 KUH Pdt tersebut yang mendefinisikan perjanjian yaitu:

a. Suatu perbuatan, yang menjelaskan bahwa perjanjian hanya mungkin terjadi jika ada suatu perbuatan nyata, baik dalam bentuk ucapan, maupun tindakan secara fisik, dan tidak hanya dalam bentuk pikiran semata-mata;

b. Antara sekurangnya dua orang (jadi dapat lebih dari dua orang), yang menunjukkan bahwa suatu perjanjian tidak mungkin dibuat sendiri;

c. Perbuatan tersebut melahirkan perikatan di antara pihak-pihak yang berjanji tersebut, mempertegas bahwa perjanjian melibatkan sekurangnya dua pihak, yaitu debitur dan kreditur.

Secara lebih khususnya arti jual beli sebagai berikut Jual Beli adalah suatu persetujuan antar dua pihak, yaitu pihak yang satu menyanggupi menyerah kan suatu barang, sedang pihak lain menyanggupi membayar harga yang sudah ditentukan untuk barang itu. ${ }^{14}$

Syarat sahnya suatu perjanjian seperti yang terdapat dalam pasal 1320 Kitab Undang-Undang Hukum Perdata merupakan syarat sahnya perjanjian jual beli dimana perjanjian jual beli merupakan salah satu jenis dari perjanjian. Pasal 1320 Kitab Undang-Undang Hukum Perdata menyatakan bahwa syarat dari sahnya perjanjian.

13 “Kitab Undang-Undang Hukum Dagang [Wetboek van Koophandel]. Translated by Subekti Dan R. Tjitrosudibio. Jakarta : Pradnya Paramita, 2002" (n.d.).

14 Raharjo Handri, Buku Pintar Transaksi Jual Beli Dan Sewa Menyewa, 1st ed. (Jakarta: Pustaka Yustisia, 2010). 
Perjanjian adalah adanya suatu kesepakatan atau konsensus pada para pihak. Yang dimaksud dengan kesepakatan adalah persesuaian kehendak antara para pihak dalam perjanjian. Jadi dalam hal ini tidak boleh adanya unsur pemaksaan kehendak dari salah satu pihak pada pihak lainnya. sepakat juga dinamakan suatu perizinan, terjadi oleh karena kedua belah pihak sama-sama setuju mengenai hal-hal pokok dari suatu perjanjian yang akan diadakan.

Cakap artinya adalah kemampuan untuk melakukan suatu perbuatan hukum yang dalam hal ini adalah membuat suatu perjanjian. Perbuatan hukum adalah segala perbuatan yang dapat menimbulkan akibat hukum. Orang yang cakap untuk melakukan perbuatan hukum adalah orang yang sudah dewasa. Ukuran kedewasaan adalah berumur 21 tahun sesuai dengan pasal 330 Kitab Undang-Undang Hukum Perdata. Dalam pasal 1330 disebutkan bahwa orang yang tidak cakap untuk melakukan perbuatan hukum adalah:

1. Orang yang belum dewasa

2. Orang yang dibawah pengampuan

Suatu hal tertentu disebut juga dengan objek perjanjian. Objek perjanjian harus jelas dan ditentukan oleh para pihak yang dapat berupa barang maupun jasa namun juga dapat berupa tidak berbuat sesuatu. Objek perjanjian juga biasa disebut dengan Prestasi. Prestasi terdiri atas:

1. memberikan sesuatu, misalnya membayar harga, menyerahkan barang.

2. berbuat sesuatu, misalnya memperbaiki barang yang rusak, membangun rumah, melukis suatu lukisan yang dipesan.

3. tidak berbuat sesuatu, misalnya perjanjian untuk tidak mendirikan suatu bangunan, perjanjian untuk tidak menggunakan merek dagang tertentu.

Di dalam Pasal 1320 Kitab Undang-Undang Hukum perdata tidak dijelaskan pengertian sebab yang halal. Yang dimaksud dengan sebab yang halal adalah bahwa isi perjanjian tersebut tidak bertentangan dengan peraturan perundang-undangan, kesusilaan dan ketertiban umum. ${ }^{15}$

${ }^{15}$ Kitab Undang-Undang Hukum Dagang [Wetboek van Koophandel]. Diterjemahkan oleh Subekti dan R. Tjitrosudibio. Jakarta : Pradnya Paramita, 2002. 
Syarat pertama dan kedua merupakan syarat subjektif karena berkaitan dengan subjek perjanjian dan syarat ketiga dan keempat merupakan syarat objektif karena berkaitan dengan objek perjanjian. Apabila syarat pertamadan syarat kedua tidak terpenuhi, maka perjanjian itu dapat diminta pembatalannya. Pihak yang dapat meminta pembatalan itu adalah pihak yang tidak cakap atau pihak yang memberikan ijinnya secara tidak bebas.

Sedangkan apabila syarat ketiga dan keempat tidak terpenuhi, maka akibatnya adalah perjanjian tersebut batal demi hukum artinya perjanjian tersebut dianggap tidak pernah ada sama sekali sehingga para pihak tidak dapat menuntut apapun apabila terjadi masalah di kemudian hari.

a) Macam-macam Jual Beli

Jual beli dibedakan dalam banyak pembagian berdasarkan sudut pandang. Adapunpengklasifikasian jual beli adalah sebagai berikut :16

1. Berdasarkan Objeknya: Jual beli berdasarkan objek dagangnya terbagi menjadi tiga jenis, yaitu:

a. Jual beli umum, yaitu menukar uang dengan barang.

b. Jual beli as-Sharf (Money Changer), yaitu penukaran uang dengan uang.

c. Jual beli muqayadhah (barter), yaitu menukar barang dengan barang.

2. Berdasarkan Standardisasi Harga:

a. Jual Beli Bargainal (tawar menawar), yaitu jual beli di mana penjual tidak memberitahukan modal barang yang dijualnya.

b. Jual Beli Amanah, yaitu jual beli di mana penjual memberitahukan modal barang yang dijualnya. Dengan dasar ini, jual beli ini terbagi menjadi tiga jenis:

c. Jual beli murabahah: jual beli dengan modal dan keuntungan yang diketahui.

d. Jual beli wadhi'ah: jual beli dengan harga di bawah modal dan kerugian yang diketahui.

e. Jual beli tauliyah: jual beli dengan menjual barang sama dengan harga modal, tanpa keuntungan atau kerugian.

3. Cara Pembayaran

Berdasarkan dari cara pembayaran, jual beli dibedakan menjadi empat macam :

16 R Subekti, Aneka Perjanjian, 10th ed. (Jakarta: Citra Aditya Bakti, 2010). 
a. Jual beli dengan penyerahan barang dan pembayaran secara langsung (jual beli kontan).

b. Jual beli dengan pembayaran tertunda (jual beli nasi'ah)

c. Jual beli dengan penyerahan barang tertunda.

d. Jual beli dengan penyerahan barang dan pembayaran sama-sama tertunda

Asas-asas yang terdapat dalam suatu perjanjian umumnya terdapat dalam perjanjian jual beli. Dalam hukum perjanjian ada beberapa asas, namun secara umum asas perjanjian ada lima yaitu Asas Kebebasan Berkontrak ${ }^{17}$, Asas Konsensualisme ${ }^{18}$ Menurut Subekti, arti dari Asas Konsensualisme (Konsensualitas): 19 Asas Konsensualisme memperlihatkan bahwa:20

“... pada dasarnya suatu perjanjian yang dibuat secara lisan antara dua atau lebih orang telah mengikat, dan arenanya telah melahirkan kewajiban bagi salah satu atau lebih pihak dalam perjanjian tersebut, segera setelah orang-orang tersebut mencapai kesepakatan atau consensus, meskipun kesepakatan tersebut telah dicapai secara lisan semata-mata."

Ketentuan mengenai Asas Konsensualisme ini dapat kita lihat dalam Pasal 1320 KUH Pdt, yang berbunyi:

Untuk sahnya suatu perjanjian diperlukan empat syarat:

1. Sepakat mereka yang mengikatkan dirinya;

2. Kecakapan untuk membuat suatu perikatan;

3. Suatu hal tertentu;

4. Suatu sebab yang halal.

Dalam KUH Pdt tidak ada perumusan lebih lanjut mengenai formalitas kesepakatan yang harus dipenuhi, kecuali dalam beberapa ketentuan khusus, seperti misalnya yang terdapat dalam ketentuan mengenai hibah dalam Pasal 1683 KUH Pdt, yang berbunyi:

"Tiada suatu hibah mengikat si penghibah, atau menerbitkan sesuatu akibat yang bagaimanapun, selain mulai hari penghibahan itu dengan kata-kata yang tegas telah diterima oleh si penerima hibah sendiri atau oleh seorang yang dengan suatu akta otentik

17 Kitab Undang-Undang Hukum Dagang [Wetboek van Koophandel]. Diterjemahkan oleh Subekti dan R. Tjitrosudibio. Jakarta : Pradnya Paramita, 2002.

18 Salim H.S, Hukum Kontrak: Teori Dan Teknik Penyusunan Kontrak, 7th ed. (Jakarta: Sinar Grafika, 2010), P. 10.

${ }^{19}$ R. Subekti, Hukum Perjanjian, 19th ed. (Jakarta: Intermasa, 2002), P. 15.

${ }^{20}$ Kartini Muljadi and Gunawan Widjaja, Perikatan Yang Lahir Dari Perjanjian, 5th ed. (Jakarta: Raja Grafindo Persada, 2010), P. 34. 
oleh si penerima hibah itu telah dikuasakan untuk menerima penghibahan-penghibahan yang telah diberikan kepada si penerima hibah atau akan diberikan kepadanya di kemudian hari."

Jika penerimaan tersebut tidak telah dilakukan di dalam suarat hibah sendiri, maka itu akan dapat dilakukan di dalam suatu akta otentik terkemudian, yang aslinya harus disimpan, asal yang demikian itu dilakukan di waktu si penghibah masih hidup; dalam hal mana penghibahan, terhadap orang yang belakangan disebut ini, hanya akan berlaku sejak hari penerimaan itu diberitahukan kepadanya.

Selanjutnya Asas mengikatnya suatu perjanjian. Asas ini terdapat dalam pasal 1338 ayat (1) Kitab Undang-Undang Hukum Perdata dimana suatu perjanjian yang dibuat secara sah berlaku sebagai undang-undang bagi pembuatnya. Setiap orang yang membuat kontrak terikat untuk memenuhi kontrak tersebut karena kontrak tersebut mengandung janji-janji yang harus dipenuhi dan janji tersebut mengikat para pihak sebagaimana mengikatnya undang-undang. Perjanjian harus dilaksanakan dengan iktikad baik (Pasal 1338 ayat (3) KUHPerdata). Iktikad baik ada dua yaitu:

1. Bersifat objektif, artinya mengindahkan kepatutan dan kesusilaan.

2. Bersifat subjektif, artinya ditentukan sikap batin seseorang.

Asas Kepribadian Pada umumnya tidak seorang pun dapat mengadakan perjanjian kecuali untuk dirinya sendiri. Pengecualiannya terdapat dalam pasal 1317 Kitab Undang-Undang Hukum Perdata tentang janji untuk pihak ketiga.

\section{KESIMPULAN}

Dalam aspek kaidah persamaan yaitu semua barang boleh dijual. Berdasarkan hukum Islam walaupun dasarnya semua barang boleh dijual, namun apabila bertentang dengan Al-Qur'an dan Hadits, atau asas kemaslahatan maka tetap dilarang. Sedangkan secara konvensional semua barang hakekatnya mutlak untuk dijual, selama ada kerelaan kedua belah pihak. Dalam Islam, transaksi jual beli melihat dari sisi objek, subjek, dan pertukaran, serta halal, haram dari suatu barang yang dijual.

\section{DAFTAR PUSTAKA}

Abdul Aziz Muhammad Azzam. Fiqh Muamalat. Jakarta: Amza, 2010.

Ahmad Izzan, and Syahri Tanjung. Referensi Ekonomi Syari'ah. Bandung: Remaja Rosdakarya, 2006. 
Dede Nurohman. Memahami Dasar-Dasar Ekonomi Islam. Yogyakarta: Teras, 2011.

Departemen Agama RI. Al-Qur'an Dan Terjemahannya. Bandung: Diponegoro, 2008.

Heri Sudarsono. Bank Dan Lembaga Keuangan Syari'ah. Yogyakarta: Ekonisa, 2013.

Kartini Muljadi, and Gunawan Widjaja. Perikatan Yang Lahir Dari Perjanjian. 5th ed. Jakarta: Raja Grafindo Persada, 2010.

Kitab Undang-Undang Hukum Dagang [Wetboek van Koophandel]. Diterjemahkan oleh Subekti dan R. Tjitrosudibio. Jakarta : Pradnya Paramita, 2002 (n.d.).

"Kumpulan Makalah Mahasiswa." Accessed January 31, 2019. http:/ / evendimuhtar.blogspot.com/2015/07/jual-beli-dalamislam.html,\%20Diakses:\%2028\%20April\%202016.

Mahmud Yunus, and Nadlrah Naimi. Fiqih Muamalah. Medan: Ratu Jaya, 2011.

R. Subekti. Aneka Perjanjian. 10th ed. Jakarta: Citra Aditya Bakti, 2010.

R. Subekti. Hukum Perjanjian. 19th ed. Jakarta: Intermasa, 2002.

Raharjo Handri. Buku Pintar Transaksi Jual Beli Dan Sewa Menyewa. 1st ed. Jakarta: Pustaka Yustisia, 2010.

Salim H.S. Hukum Kontrak: Teori Dan Teknik Penyusunan Kontrak. 7th ed. Jakarta: Sinar Grafika, 2010.

SKJ: Islam Untuk Kesejahteraan Masyarakat. Accessed January 31, 2019. https://books.google.com/books/about/SKJ_Islam_Untuk_Kesejahteraan_Ma syarakat.html?id=7JBBDwAAQBAJ. 